\title{
Human Exposure Assessment to Potentially Toxic Elements (PTEs) from Tofu Consumption
}

\section{Soraya Paz ( $\nabla$ spazmont@ull.edu.es )}

University of La Laguna https://orcid.org/0000-0003-0878-7138

\section{Carmen Rubio}

Universidad de la Laguna

Ángel J. Gutiérrez

Universidad de la Laguna

Dailos González-Weller

Servicio Canario de Salud

\section{Arturo Hardisson}

Universidad de la Laguna

\section{Research Article}

Keywords: Tofu, potentially toxic elements, risk assessment, food safety, organic crop, toxic risk

Posted Date: February 18th, 2021

DOI: https://doi.org/10.21203/rs.3.rs-171049/v1

License: (1) This work is licensed under a Creative Commons Attribution 4.0 International License. Read Full License

Version of Record: A version of this preprint was published at Environmental Science and Pollution Research on February 27th, 2021. See the published version at https://doi.org/10.1007/s11356-021-13076-5. 


\section{Abstract}

Potentially toxic elements (PTEs) ( $\mathrm{V}, \mathrm{B}, \mathrm{Ba}, \mathrm{Li}, \mathrm{Sr}, \mathrm{Cr}, \mathrm{Ni}, \mathrm{Al}, \mathrm{Pb}, \mathrm{Cd})$ were determined in 130 samples of different tofu types (natural, flavoured, smoked and fresh made) by ICP-OES (inductively coupled plasma optical emission spectrometry). Al was the most notable element found with the highest concentration $(6.71 \mathrm{mg} / \mathrm{kg}$ ww) found in flavoured tofu. Ni level $(0.38 \mathrm{mg} / \mathrm{kg})$ stands out in smoked tofu. European tofu has higher PTEs levels than Chinese tofu. Organic produced tofu has higher PTEs concentrations than conventional produced tofu. $200 \mathrm{~g} /$ day of smoked tofu confers a contribution percentage of $39.6 \%$ of its TDI (tolerable daily intake). In addition, $200 \mathrm{~g} /$ day of flavoured tofu would mean a high $\mathrm{Pb}$ contribution with a $23.2 \%$ of the BMDL (benchmark dose level) set in $0.63 \mu \mathrm{g} / \mathrm{kg}$ bw/day to the development of nephrotoxicity. Mean consumption would not pose a risk to adults' health. Considering the obtained results, it would be advisable to establish limits for certain metals such as $\mathrm{Pb}, \mathrm{Al}$ and $\mathrm{Ni}$ in this type of product. Furthermore, it is recommendable to set consumer guidelines to some tofu types in order to avoid excessive intake of PTEs.

\section{Chemical Compounds}

Nitric acid (PubChem: CID 944)

\section{Introduction}

One the most important food in the diet of the Asian countries is the tofu. Tofu is a product made by the fermentation of soybeans. The nutritional composition of tofu is remarkably, for that reason, tofu has increasing its consumption in Western countries like USA and European countries.

Tofu is an important source of proteins, lipids, vitamins, amino acids and minerals (Serrazanetti et al., 2013; Xu et al., 2015) and, as a result, tofu is a key product in the vegetarians and vegans diets, where is used as a meat products substitute (Fang et al., 2005; Serrazanetti et al., 2013; Meng et al., 2016).

The diet is the main route of human exposure to pollutants from natural and anthropogenic sources (Bocio et al., 2005; Di Bella et al., 2020), especially due to the use of fertilizers and industrial activity. Potentially toxic elements (PTEs) such as aluminium (Al), cadmium (Cd) and lead $(\mathrm{Pb})$ tend to accumulate, do not have any function in the human body and are harmful to health (Marini et al., 2021).

Al is a known neurotoxic agent that tends to accumulate mostly in the brain and relationships between high concentrations of this metal in the brain and neurodegenerative diseases such as Alzheimer's disease have been reported (Arvand and Kermanian, 2012; Hardisson et al., 2017). Pb is one of the most well-known contaminants and, is another neurotoxic metal that causes serious damage to the central nervous system (Rubio et al., 2005; Nordberg et al., 2007). Cd is a toxic and bioaccumulative metal characterized by a long half-life (Barbier et al., 2005; Kumar and Sharma, 2019), and Cd competes in the organism with other essential elements such as Zn, Fe or Cu causing serious damage to the renal system (Rubio et al., 2017b). Cd levels are high in plant products such as tofu and diet is the main Cd exposure for non-smoker population (Kosečková et al., 2020). 
Other PTEs such as B, Ba, Ni, Li, Sr, or V, are found naturally in the environment and, therefore, in food. In addition, these elements are mainly found in cereals, vegetables, and legumes. They do not have a known function in the human organism, but they are essential for other animal and plant organisms (IOM 2001; WHO 2010; SCHER 2012; González-Weller et al. 2015; Rubio et al. 2017b). Although they are usually found at trace levels, anthropogenic activities can increase their concentrations which would lead to different toxic effects. Although food poisoning due to the ingestion of these PTEs has not been described, it is necessary to consider their harmful effects on health.

Studies carried out with experimental animals show that B affects development, and the reproductive system and $\mathrm{V}$ can cause kidney damage (IOM, 2001). Ba is an element that acts as an antagonist of $\mathrm{K}$ and $\mathrm{Ca}$ and tends to accumulate in bones (Kato et al., 2020). Ni is an element that can cause dermatitis, especially harmful in individuals with hypersensitivity or kidney problems (Das et al., 2018). Sr is an element that can cause P deficiency, and, in addition, it accumulates in the bones (Pathak and Gupta 2020). High Li intakes could lead to kidney damage and blindness (Domínguez-Ortega et al., 2006).

Soybeans, a key ingredient in tofu, can accumulate potentially toxic elements from environmental pollution, irrigated water, pesticides, fertilizers, and contaminated soils (Tóth et al., 2016; Gu et al., 2016; Shaheen et al., 2016). Therefore, it is necessary to determine the content of PTEs in this type of products and, if were necessary, to set some recommendations to avoid the risks.

Considering the growing consumption of tofu in Western countries, the great absorption capacity of soybean plants and the possible presence of high PTEs levels in derivatives such as tofu, this study has been conducted with the objective of determining the concentration of potentially toxic elements (PTEs) ( $\mathrm{V}, \mathrm{B}, \mathrm{Ba}, \mathrm{Li}$, $\mathrm{Sr}, \mathrm{Cr}, \mathrm{Ni}, \mathrm{Al}, \mathrm{Pb}, \mathrm{Cd}$ ) in different tofu types (European vs Chinese, organic vs conventional, types) by inductively coupled plasma atomic emission spectroscopy (ICP-OES) to assess its toxic risk.

\section{Material And Methods}

During the samples treatment and the analysis were used chemical reagents of analytical grade and deionized water of high purity obtained from a purification system of the trademark Mili-Q (Milipore, MA, USA) (Paz et al., 2020).

\subsection{Samples}

A total of 130 tofu samples were analysed. The samples were acquired in local organic food shops, hypermarkets, and Chinese superstores. The samples were stored at $4^{\circ} \mathrm{C}$ in a conventional fridge. The characteristics of the analysed samples are in the Table 1. 
Table 1

Characteristics of the analysed samples

\begin{tabular}{|llll|}
\hline Type & Origin & Production & No \\
\hline Natural & EU & Organic & 20 \\
\hline Flavoured & EU & Organic & 20 \\
\hline Smoked & EU & Organic & 20 \\
\hline Natural & EU & Conventional & 20 \\
\hline Natural & China & Conventional & 30 \\
\hline Fresh homemade & China* & Conventional & 20 \\
\hline *Fresh homemade conventional tofu made in Chinese supermarkets with ingredients from China. \\
\hline
\end{tabular}

\subsection{Sample treatment}

$10 \mathrm{~g}$ of each previously homogenized sample were weighed in porcelain crucibles (Königliche, Germany). The samples were placed in an oven (Nabertherm, Gemany) for dehydration at $70^{\circ} \mathrm{C}-24 \mathrm{~h}$. Then, the samples were subjected to acid digestion with $65 \%$ nitric acid $\left(\mathrm{HNO}_{3}\right)$ (Merck, Germany). Subsequently, the samples were subjected to incineration in a muffle furnace (Nabertherm, Germany) with a temperature - time program of $400^{\circ} \mathrm{C}-24 \mathrm{~h}$, with a progressive rise $50^{\circ} \mathrm{C}$ per hour (Hardisson et al. 2001; Gutiérrez et al., 2008; Paz et al., 2020). The ashes were dissolved in nitric acid $\left(\mathrm{HNO}_{3}\right)$ (Merck, Germany) at $1.5 \%$ to a volume of $25 \mathrm{~mL}$.

\subsection{Method and quality control}

The PTE content was determined using an inductively coupled plasma atomic emission spectrometer (ICPOES) model ICAP 6300 Duo Thermo Scientific. ICP-OEs is a technique commonly used in the determination of trace and toxic elements (Chaves et al., 2010; Karasakal, 2020). The ICP-OES instrumental conditions were: RF power, $1150 \mathrm{~W}$; gas flow (nebulizer gas flow, auxiliary gas flow), $0.5 \mathrm{~L} / \mathrm{min}$; injection of the sample to the flow pump, 50 rpm; stabilization time, 0 s (Rubio et al. 2018; Paz et al. 2020). The instrumental wavelengths (nm) of the analysed PTEs were Al (167), B (249.7), Ba (455.4), Cd (226.5), $\mathrm{Cr}$ (267.7), Li (670.8), Ni (231.6), Pb (220.3), Sr (407.7), V (310.2).

Calibration curves were prepared every day before the sample analysis by using a multi-element stock solution Multi-Element Stds. SCP28AES of $100 \mathrm{mg} / \mathrm{L}$ of Al, B, Ba, Cd, Ni, Li, Pb, Sr and V (SCP Science, Baie-D'Urfe, QC, Canada). The calibration curve was prepared using a solution of $1.5 \%$ of nitric acid $\left(\mathrm{HNO}_{3}\right)($ Merck, Darmstadt, Germany).

The LOQ (limits of quantifications) of the PTEs were calculated, under conditions of reproducibility, such as ten times the standard deviation (SD) obtained from the analysis of 15 targets (IUPAC, 1995), the values of the LOQs (mg/L) were Al (0.012), B (0.012), Ba (0.005), Cd (0.001), Li (0.013), Ni (0.003), Pb (0.001), Sr (0.003), V (0.005). 
The analytical procedure accuracy and precision was verified by performing quality controls based on the recovery percentage study obtained with the reference material under reproducible conditions (Table 2). The reference materials used in this study were Tomato Leaves (NIST SRM 1573a, Gaithersburg, MD, USA), Bovine Liver (NIST SRM 1577b, Gaithersburg, MD, USA) and Oyster Tissue (NIST SRM 1566b, Gaithersburg, MD, USA). The percentages of recovery obtained were higher than $93 \%$; furthermore, no significant differences were found between the concentrations found and those certified by the manufacturer.

Table 2

Recovery percentage found for the reference materials used

\begin{tabular}{|lllll|}
\hline Reference material & Metal & $\begin{array}{l}\text { Certified C. } \\
(\mathbf{m g} / \mathbf{k g})\end{array}$ & $\begin{array}{l}\text { Obtained C. } \\
(\mathbf{m g} / \mathbf{k g})\end{array}$ & $\begin{array}{l}\text { R } \\
\mathbf{( \% )}\end{array}$ \\
\hline SRM 1577b Bovine Liver & $\mathrm{Sr}$ & $0.136 \pm 0.001$ & $0.138 \pm 0.002$ & 101.3 \\
& $\mathrm{Al}$ & 3 & $3.1 \pm 0.12$ & 103.7 \\
& $\mathrm{~Pb}$ & $0.129 \pm 0.004$ & 0.122 & 94.4 \\
\cline { 2 - 5 } & $\mathrm{Cd}$ & $0.5 \pm 0.03$ & 0.47 & 93.1 \\
\hline SRM 1566 b Oyster Tissue & $\mathrm{B}$ & $4.5 \pm 1.9$ & $4.35 \pm 1.2$ & 96.7 \\
\cline { 2 - 5 } & $\mathrm{Ba}$ & $8.6 \pm 0.3$ & $8.15 \pm 0.9$ & 94.8 \\
\cline { 2 - 5 } & $\mathrm{Ni}$ & $1.04 \pm 0.09$ & $0.99 \pm 0.12$ & 95.3 \\
\cline { 2 - 5 } & $\mathrm{V}$ & $0.5389 \pm 0.09$ & 0.577 & 93.4 \\
\hline Method of standard addition & $\mathrm{Li}$ & 1.81 & $1.804 \pm 0.087$ & 99.7 \\
\hline SRM 1573a Tomato Leaves & $\mathrm{Cr}$ & $1.95 \pm 0.09$ & 1.99 & 98.1 \\
\hline
\end{tabular}

\subsection{Statistical analysis}

The statistical study of the data was performed using the statistical program statistical program IBM Statistics SPSS 22.0 for Mac®. The aim of the statistical analysis is to determine the significative differences $(p<0.05)$ considering the different factors: production (conventional vs organic), type (natural, smoked and flavoured), origin (Europe vs China).

The Kolmogorov-Smirnov and Shapiro-Wilk tests were used to study the data distribution (Rubio et al., 2017b). Then, the Kruskal-Wallis non-parametric test was applied to data that did not follow a normal distribution. In case of significative differences, was applied the Mann-Whitney U test (Gutiérrez et al., 2008; Paz et al., 2020). The parametric ANOVA test was used for data that followed a normal distribution and the Tukey Post Hoc test was applied in the case of the existence of significant differences.

A correlation study was carried out to detect positive or negative correlation between the PTEs analysed.

\subsection{Risk assessment calculation}


The risk assessment was conducted by the calculation of the estimated daily intake (EDI). The EDI is the quantity of potentially toxic elements ingested with a serving of tofu.

$\operatorname{EDI}(\mathrm{mg} /$ day $)=$ PTE concentration $(\mathrm{mg} / \mathrm{kg}) \cdot$ Tofu consumption $(\mathrm{kg} /$ day $)$

Then, the contribution percentages (\%) to the guideline values were obtained by the following expression:

Contribution $(\%)=[$ EDI $/$ Guideline values $] \cdot 100$

\section{Results And Discussion}

\subsection{Concentration of metals in tofu}

Table 3 shows the mean average concentrations obtained ( $\mathrm{mg} / \mathrm{kg}$ wet weight) and the standard deviation (SD) of the tofu samples by its origin (China vs Europe), production type (conventional vs organic) and by tofu type (natural, smoked, flavoured, homemade).

Table 3

Mean concentrations ( $\mathrm{mg} / \mathrm{kg}$ wet weight) and standard deviations (SD) of the PTEs by tofu type

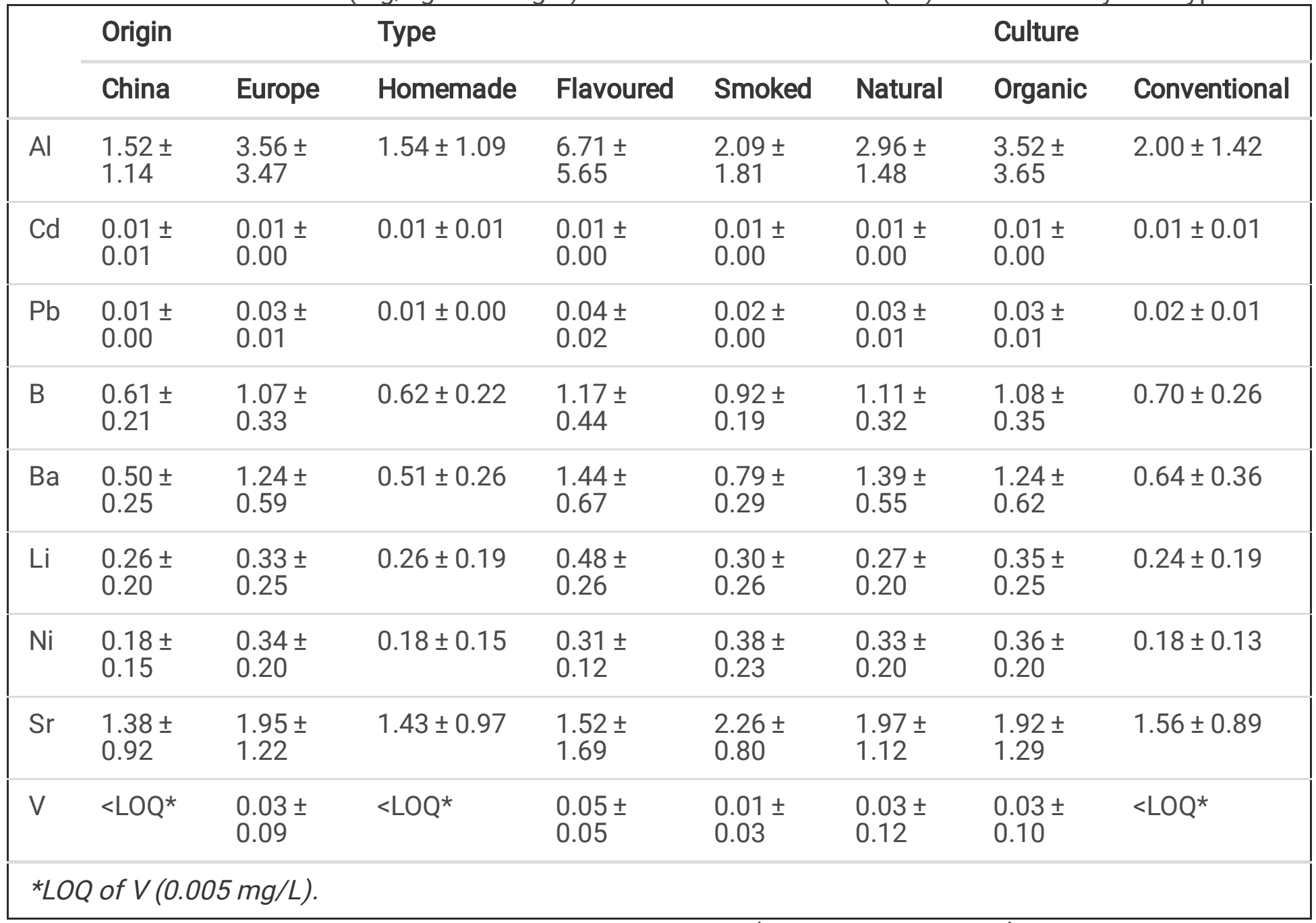


The concentration of PTEs was higher in European tofu than Chinese tofu. The most remarkable PTEs found in EU tofu were Al (3.56 mg/kg ww), Sr (1.95 mg/kg ww), Ba (1.24 mg/kg ww) and B (1.07 mg/kg ww). In addition, $\mathrm{Pb}(0.003 \mathrm{mg} / \mathrm{kg} \mathrm{ww})$ level was higher in the tofu from Europe than in the Chinese tofu. The statistical analysis shown significant differences between both origins for all the potentially toxic elements studied, except for Li.

In summary, the European tofu content high PTEs levels than the tofu from China. The differences found between both origins are due to several factors like environment, soil, irrigation water, etc. This fact is not positive, because European countries have more legal control over the pollution than China, which is an industrialized country. So, it is necessary to establish maximum limits for these metals, especially $\mathrm{Al}, \mathrm{Pb}$ and $\mathrm{Ni}$ in tofu.

\subsubsection{PTEs concentration by production type (conventional vs organic)}

According to the type of production of the tofu, the PTEs levels found in the organic tofu were higher than the conventional tofu. The levels of Al (3.52 mg/kg ww), Sr (1.92 mg/kg ww), Ba (1.24 mg/kg ww), and B (1.08 $\mathrm{mg} / \mathrm{kg} \mathrm{ww}$ ) were notable. Significant differences were also detected between the two types for all the trace metals studied, except Li.

Organic produced tofu has a stronger metal profile than conventionally produced tofu. This is a disadvantage because organic products should have lower levels of pollutants like PTEs than conventional products.

Although, organic products are subject to lower amounts of pesticides and/or chemical agents, it is necessary to bear in mind other factors such as soil, environment, irrigation water, tofu water, etc. (Hornick, 2009). Normally, the control under organic products is focused on the levels of pesticides, but, considering the results obtained in the present study, it is necessary to consider other factors that could increase the levels of pollutants like PTEs.

\subsubsection{PTEs concentration by type of tofu (natural, flavoured, smoked, homemade)}

Al stands out in the four types studied and the highest mean Al level $(6.71 \mathrm{mg} / \mathrm{kg} \mathrm{ww})$ was found in the flavoured tofu. The Pb level $(0.04 \mathrm{mg} / \mathrm{kg} \mathrm{ww})$ is also noteworthy in the flavoured tofu, which was the highest in all the types of tofu. Likewise, the tofu containing algae have the highest concentrations of $\mathrm{Al}, \mathrm{Cd}$ and $\mathrm{Pb}$. This is also due to the high metal absorption capacity of algae (Khan et al., 2015; Rubio et al., 2017b). In addition, the content of $\mathrm{Al}$ and $\mathrm{Pb}$ found in the flavoured tofu differs statistically from the content found in the other three types.

Is remarkably the Sr content found in the four types of tofu studied and it is worth mentioning the level of $\mathrm{Sr}$ $(2.26 \mathrm{mg} / \mathrm{kg} \mathrm{ww})$ found in the smoked tofu. On the other hand, the level of $\mathrm{Ni}(0.38 \mathrm{mg} / \mathrm{kg} \mathrm{ww})$ found in smoked tofu is also noteworthy, which could be due to the wood used in the smoking process of this type of tofu, which, according to the manufacturer, is beech and oak wood. Studies have shown that beech and oak trees can accumulate metals from the absorption of these metals through the soil (Queirolo et al. 1990; Pastircakova 2004), which, when the wood is heated, could pass to the tofu. 
After performing the statistical analysis, significant differences were detected in the Li content found in the flavoured tofu, which differ significantly from the other three types (homemade, smoked, and natural). Besides which, the level of $\mathrm{Ni}$ is statistically significant between the homemade tofu and the other types, with the lowest $\mathrm{Ni}$ content $(0.18 \mathrm{mg} / \mathrm{kg} \mathrm{ww})$ being found in the flavoured tofu.

The differences found in the metal content of the four types of tofu studied may be due to several factors, such as other ingredients (cereals, algae, additives, etc.) in the case of flavoured tofu or, for example, in the case of smoked tofu, the smoking process can significantly influence the metal content, as well as the water or the coagulating agent used in its production etc.

\subsection{Correlations between PTEs}

Table 4 shows the correlation values between the studied PTEs. The correlations study have revealed some negative and positive correlations between almost of the PTEs analysed. The strong negatives correlations were found between Cd-Ni with a Spearman's Rho correlation of -0.531 , that is interesting because it shows a possible competition among $\mathrm{Cd}$ and $\mathrm{Ni}$. This correlation value means that when $\mathrm{Cd}$ levels arise the $\mathrm{Ni}$ levels decrease and vice versa.

Table 4

Data from the Spearman's Rho correlation study between the studied PTEs

\begin{tabular}{|c|c|c|c|c|c|c|c|c|c|}
\hline & Al & B & $\mathrm{Ba}$ & $\mathrm{Cd}$ & $\mathrm{Li}$ & $\mathrm{Ni}$ & $\mathrm{Pb}$ & $\mathrm{Sr}$ & $\mathrm{V}$ \\
\hline $\mathrm{Al}$ & 1 & & & & & & & & \\
\hline$B$ & $0.459 *$ & 1 & & & & & & & \\
\hline $\mathrm{Ba}$ & $0.329 *$ & $0.441^{*}$ & 1 & & & & & & \\
\hline $\mathrm{Cd}$ & $0.147^{*}$ & $-0.145^{\star}$ & $-0.194^{*}$ & 1 & & & & & \\
\hline $\mathrm{Li}$ & $0.218^{\star}$ & $0.078^{\star}$ & $0.039 *$ & $0.011^{*}$ & 1 & & & & \\
\hline $\mathrm{Ni}$ & $-0.291^{*}$ & $0.149 *$ & $0.291^{*}$ & $-0.531^{\star}$ & 0.005 & 1 & & & \\
\hline $\mathrm{Pb}$ & $0.884^{\star}$ & $0.574^{\star}$ & $0.557^{*}$ & $-0.019 *$ & $0.237^{*}$ & $-0.061^{*}$ & 1 & & \\
\hline $\mathrm{Sr}$ & $-0.222^{\star}$ & $0.103^{\star}$ & $-0.065^{\star}$ & $0.212^{\star}$ & $-0.107^{*}$ & $0.185^{\star}$ & $-0.144^{\star}$ & 1 & \\
\hline $\mathrm{V}$ & -0.008 & $0.020^{*}$ & $0.218^{*}$ & $-0.171^{\star}$ & 0.004 & $0.170 *$ & $0.033^{\star}$ & $-0.048^{\star}$ & 1 \\
\hline
\end{tabular}

According to the positive correlations, it is remarkably the Spearman's Rho correlation found between Al-Pb (0.884). This value, near to 1 , shows that both elements does not compete and when Al levels increasing, the $\mathrm{Pb}$ levels too.

\subsection{Human exposure assessment}

Table 5 shows the guide values of the maximum admissible intakes set by different institutions. The estimated daily intakes (EDIs) were calculated considering a mean consumption of $200 \mathrm{~g}$ of tofu daily, which is equivalent to one portion. The average weight of an adult was $68.48 \mathrm{~kg}($ AESAN, 2006) (Table 6). 
Table 5

Maximum reference intake values set by different institutions

\begin{tabular}{|c|c|c|c|}
\hline & Parameter & Value & Reference \\
\hline $\mathrm{Al}$ & \multirow[t]{2}{*}{ TWI } & $1 \mathrm{mg} / \mathrm{kg}$ bw/week & EFSA, 2011a \\
\hline $\mathrm{Cd}$ & & $2.5 \mu \mathrm{g} / \mathrm{kg} \mathrm{bw} /$ week & EFSA, 2011b \\
\hline $\mathrm{Sr}$ & \multirow[t]{3}{*}{ TDI } & $0.13 \mathrm{mg} / \mathrm{kg}$ bw/day & WHO, 2010 \\
\hline $\mathrm{Ba}$ & & $200 \mu \mathrm{g} / \mathrm{kg}$ bw/day & SCHER, 2012 \\
\hline $\mathrm{Ni}$ & & $2.8 \mu \mathrm{g} / \mathrm{kg} \mathrm{bw} / \mathrm{day}$ & EFSA, 2015 \\
\hline \multirow[t]{2}{*}{$\mathrm{Pb}$} & $\mathrm{BMDL}_{\text {Nephrotoxicity }}$ & $0.63 \mu \mathrm{g} / \mathrm{kg}$ bw/day & EFSA, 2011 \\
\hline & $\mathrm{BMDL}_{\text {Cardiovascular }}$ & $1.50 \mu \mathrm{g} / \mathrm{kg}$ bw/day & \\
\hline $\mathrm{B}$ & \multirow[t]{2}{*}{ UL } & $17-20 \mathrm{mg} /$ day & IOM, 2001 \\
\hline $\mathrm{V}$ & & $1.8 \mathrm{mg} /$ day & \\
\hline
\end{tabular}

Table 6

Estimated daily intakes (EDI) and percentages of contribution to the reference values set by different institutions

\begin{tabular}{|c|c|c|c|c|c|c|c|c|}
\hline & \multicolumn{4}{|l|}{ EDI (mg/day) } & \multicolumn{3}{|c|}{ Contribution (\%) } & \multirow[b]{2}{*}{ Natura } \\
\hline & Homemade & Flavoured & Smoked & Natural & Homemade & Flavoured & Smoked & \\
\hline $\mathrm{Al}$ & 0.31 & 1.34 & 0.42 & 0.59 & 3.16 & 13.7 & 4.27 & 6.10 \\
\hline $\mathrm{Cd}$ & 0.003 & 0.002 & 0.002 & 0.002 & 11.0 & 8.07 & 9.26 & 8.10 \\
\hline $\mathrm{Pb}^{*}$ & 0.002 & 0.01 & 0.004 & 0.01 & 4.64 & 23.2 & 9.28 & 23.2 \\
\hline $\mathrm{Pb}^{\star \star}$ & 0.002 & 0.01 & 0.004 & 0.01 & 1.95 & 9.74 & 3.90 & 9.74 \\
\hline B & 0.12 & 0.23 & 0.18 & 0.22 & 7.28 & 13.8 & 10.8 & 13.1 \\
\hline $\mathrm{Ba}$ & 0.10 & 0.29 & 0.16 & 0.28 & 0.75 & 2.11 & 1.15 & 2.03 \\
\hline $\mathrm{Li}$ & 0.05 & 0.10 & 0.06 & 0.05 & - & & & \\
\hline $\mathrm{Ni}$ & 0.04 & 0.06 & 0.08 & 0.07 & 18.7 & 32.4 & 39.6 & 34.2 \\
\hline $\mathrm{Sr}$ & 0.29 & 0.30 & 0.45 & 0.39 & 3.22 & 3.41 & 5.07 & 4.43 \\
\hline V & 0.001 & 0.01 & 0.002 & 0.01 & 0.05 & 0.52 & 0.10 & 0.35 \\
\hline
\end{tabular}

The Ni contribution (39.6\%) from the consumption of smoked tofu stands out, this contribution percentage to the TDI of $\mathrm{Ni}(2.8 \mu \mathrm{g} \mathrm{Ni} / \mathrm{kg}$ bw/day) can pose a particular risk for people with sensitivity to this element (EFSA, 
2015). The TDI of Ni would be overpassed in cases of 3 portions of smoked tofu ( $600 \mathrm{~g} / \mathrm{day})$.

In addition, the percentage of contribution of $\mathrm{Pb}$ from the consumption of flavoured tofu is noteworthy, with it a $23.2 \%$ of the BMDL (benchmark dose level) set in $0.63 \mu \mathrm{g} / \mathrm{kg} \mathrm{bw} /$ day to the development of nephrotoxicity (EFSA 2011). It is necessary to consider this contribution percentage, because the total intake of Pb from the whole diet could contribute to the $100 \%$ of the BMDL. However, a study conducted by Chen et al. (2001) a negative correlation between tofu consumption and blood Pb levels in young Chinese adults was found.

The percentage of contribution of $\mathrm{Al}(13.7 \%)$ also stands out in flavoured tofu. It should be due to the presence of some food additives (Ogimoto et al., 2016). However, the absorption of Al through the digestive system is not elevated (Oliveira et al., 2017), it is necessary to consider this contribution percentage. An alternation between flavoured and other tofu types should be recommended in order to avoid an elevate Al intake.

The Cd contribution percentage from homemade tofu is $11.0 \%$ of its TWI set in $2.5 \mu \mathrm{g} / \mathrm{kg}$ bw/week. Cd is an element that should be monitored and controlled in tofu and other soybeans products. A study conducted by Adams et al. (2011) concluded that tofu consumption is one of the specific foods that is associated with the urine $\mathrm{Cd}$ concentration. Considering that cigarette smoking is one of the major Cd source, the consumption of tofu by smokers could be a severe risk for the health.

However, considering the consumption of 200 grams of tofu per day, the intake of PTEs would not pose a risk to the health of adults. Nevertheless, is necessary to develop more studies about the PTEs in tofu and other soybean products to set limits, in special, to $\mathrm{Ni}, \mathrm{Al}, \mathrm{Cd}$ and $\mathrm{Pb}$ levels, to avoid risks to the consumers. In addition, is necessary to set consumer guidelines to some tofu types to avoid excessive intake of PTEs.

\subsection{Recommendations for tofu consumers}

The recommendations about the tofu consumption depends on different factors like type of diet (omnivorous, vegetarian or vegan), life styles (smokers or non-smokers), physiological factors (age, gender, illness, etc). However, considering the adult population, general recommendations could be done.

Figure 1 shows a proposal of recommendation guidelines for tofu consumers to avoid a overexposure to PTEs. The recommendation guidelines proposed for tofu are according to the PTEs levels found in the present study. As previously commented, the risks of tofu consumption are due to $\mathrm{Ni}, \mathrm{Pb}, \mathrm{Al}$ and $\mathrm{Cd}$ levels recorded.

Two different scenarios were proposed, 1-4 servings per week which means between 200-800 g per week, and more than 4 serving per week that means more than $800 \mathrm{~g}$ per week.

In cases of omnivorous diet, the consumption of 1-4 servings of tofu per week does not represent a health risk because in the limit case of 4 servings per week, it means a $800 \mathrm{~g} /$ week of tofu or $114 \mathrm{~g} / \mathrm{day}$ of tofu. The contribution percentages of PTEs like Ni (22.7\%), Pb (10.6\%), Al (7.83\%) and Cd (4.67\%) does not exceed the limit.

However, in the case of the same consumption ( $800 \mathrm{~g} /$ week) by a vegetarian or vegan diet, the total diet intake of $\mathrm{Ni}, \mathrm{Pb}, \mathrm{Al}$ or $\mathrm{Cd}$ could overpassed the limit intake value. A vegetarian and/or vegan person normally 
consumes high amounts of cereals, vegetables, soybean drinks, edible seaweeds, etc. This foods contain high PTEs. As previously published by Krajčovičová-Kudláčková et al. (2006) found that vegan group have the high $\mathrm{Cd}$ levels in blood. The recommendations to the vegetarian and vegan people is to vary among the different tofu types and reduce the consumption of other soybean product like soybean drinks, etc.

In cases of omnivorous diet, when the consumption of tofu is higher than $800 \mathrm{~g} /$ week a reduction of cereals and, specially, rice, should be advisable. In addition, it is recommendable to reduce the consumption of smoked and flavoured tofu, and consequently, a reduction of marine food products could be necessary. The same scenario of consumption but by vegan or vegetarian population could represent a high risk to the health, and consequently it is necessary to avoid the consumption of flavoured and smoked tofu, reduce the tofu consumption, avoid the consumption of other soybean products and avoid the consumption of edible seaweeds, which have high $\mathrm{Cd}, \mathrm{Pb}$ and $\mathrm{Al}$ levels. In the case of smokers, the $\mathrm{Cd}$ levels from tofu consumption with the Cd levels from cigarettes, should represent an extreme risk for the consumers health.

\subsection{Future perspectives}

Food production systems contribute to the environmental pollution and climate change. As a future perspectives of several countries is the reduction of the environmental impact and, as a part of this policies, the food production is a key factor. The greenhouse gas emissions and the energy demand are the best way to classified the different food production systems.

Tofu is a staple food in Asian countries, but in the last decades, the consumption of tofu by Western populations is high. This food have beneficial and nutritional properties. About the future perspectives of tofu in Western countries, it is necessary to consider that tofu is not only a valuable food from the nutritional point of view, tofu could be a sustainable food.

Heller et al. (2018) concluded that the U.S. consumption of meat and animal milk are the main producers of greenhouse gas emissions. Hendrie et al. (2016) concluded that the consumption of core foods like vegetables, dairy and grains, provide a nutritional benefit and are more environmental friendly than other food types. A study conducted by Mejia et al. (2017) evaluated the greenhouse gas emissions generated by the tofu production. The results obtained by this authors concluded that the emissions of greenhouse gas emissions from tofu production were lower than other food products.

\section{Conclusions}

The results obtained in the study show that flavoured tofu that containing other ingredients, such as seaweed, sesame, quinoa, and olives, have higher PTEs than the other tofu types. Except for Ni, whose highest level was found in smoked tofu. Likewise, organic produced tofu was found to have a higher PTEs concentrations than conventional produced tofu.

The correlation study revealed a strong negative correlations between $\mathrm{Cd}-\mathrm{Ni}$, it shows a possible competition among both elements because when Cd levels arise, the Ni levels decrease. The strong positive correlations found were between $\mathrm{Al}-\mathrm{Pb}, \mathrm{Pb}-\mathrm{Ba}$ and $\mathrm{Pb}-\mathrm{B}$, that's interesting because it shows that when $\mathrm{Pb}$ levels arise, the $\mathrm{Al}, \mathrm{Ba}$ and $\mathrm{B}$ levels decrease. 
The maximum limits are not exceeded, although, in the case of $\mathrm{Ni}$, there is a contribution percentage of $39.6 \%$ of the TDI of this metal from the consumption of smoked tofu, and this percentage should be borne in mind because individuals with sensitivity to Ni can be affected. Just $600 \mathrm{~g} /$ day (3 portions) of smoked tofu contributes more than the $100 \%$ of the TDI. The Pb contribution percentage from the flavoured tofu consumption with a $23.2 \%$ of the BMDL (benchmark dose level) set in $0.63 \mu \mathrm{g} / \mathrm{kg} \mathrm{bw} /$ day to the development of nephrotoxicity. It is necessary to consider this contribution percentage, because the total intake of $\mathrm{Pb}$ from the whole diet could contribute to the $100 \%$ of the BMDL. The percentage of contribution of $\mathrm{Al}$ (13.7\%) also stands out in flavoured tofu. The Cd contribution percentage from homemade tofu is $11.0 \%$ of its TWI set in $2.5 \mu \mathrm{g} / \mathrm{kg}$ bw/week. Considering that cigarette smoking is one of the major Cd source, the consumption of tofu by smokers should be controlled to avoid a health damage.

Considering the obtained results, it would be advisable to establish limits for certain metals such as $\mathrm{Pb}, \mathrm{Al}, \mathrm{Cd}$ and $\mathrm{Ni}$ in this type of product. Furthermore, it is recommendable to set consumer guidelines to some tofu types in order to avoid excessive intake of PTEs.

\section{Declarations}

\section{Conflict of interests}

The authors declare that they do not have any conflict of interest.

\section{Declarations}

\section{Ethical Approval}

Not applicable.

Consent to Participate

Not applicable.

Consent to Publish

Not applicable.

\section{Authors Contributions}

All authors contributed to the study conception. Design of the study was performed by $\mathrm{CR}$ and $\mathrm{AH}$. Material preparation, data collection and analysis were performed by SP, ÁJG and DGW. The first draft of the manuscript was written by SP and all authors commented on previous versions of the manuscript. All authors read and approved the final manuscript.

\section{Funding}

This manuscript has not received funding. 
The authors declare that they have no conflicts of interest.

Availability of data and materials

All data generated or analyzed during this study are included in this published article

\section{References}

1. Adams SV, Newcomb PA, Shafer MM, Atkinson C, Aiello Bowles EJ, Newton KM, Lampe JW (2011) Sources of cadmium exposure among healthy premenopausal women. Sci Total Environ 409(9):16321637. https://doi.org/10.1016/j.scitotenv.2011.01.037

2. AESAN (Agencia Española de Seguridad Alimentaria y Nutrición) (2006) Modelo de dieta española para la determinación de la exposición del consumidor a sustancias químicas. Ministerio de Sanidad y Consumo, Madrid

3. Arvand M, Kermanian M (2012) Potentiometric Determination of Aluminum in Foods, Pharmaceuticals, and Alloys by AIMCM-41-Modified Carbon Paste Electrode. Food Anal Methods 6:578-586

4. Barbier O, Jacquillet G, Tauc M, Cougnon M, Poujeol P (2005) Effect of Heavy Metals on, and Handling by, the Kidney. Nephron Physiology 99:105-110

5. Bocio A, Nadal M, Domingo JL (2005) Human exposure to metals through the diet in Tarragona, Spain. Biol Trace Elem Res 104:193-201. https://doi.org/10.1385/BTER:104:3:193

6. Chaves ES, Santos EJ, Araujo RGO, Oliveira JV, Frescura VLA, Curtius AJ (2010) Metals and phosphorus determination in vegeta-ble seeds used in the production of biodiesel by ICP OES and ICP-MS. Microchem J. https://doi.org/10.1016/j.microc.2010.01.021

7. Chen C, Wang X, Chen D, Li G, Ronnenberg A, Watanabe H, Wang X, Ryan L, Christiani DC, Xu X (2001) Tofu Consumption and Blood Lead Levels in Young Chinese Adults. Am J Epidemiol 153(12):1206-1212. https://doi.org/10.1093/aje/153.12.1206

8. Das KK, Chandramouli RR, Bagoji IB, Das S, Bagali S, Mullur L, Khodnapur JP, Biradar MS (2018) Primary concept of nickel toxicity - an overview. J Basic Clin Physiol Pharmacol 30(2):141-152. https://doi.org/10.1515/jbcpp-2017-0171

9. Di Bella C, Traina A, Giosuè C, Carpintieri D, Lo Dico GM, Bellante A, Del Core M, Falco F, Gherardi S, Uccello MM, Ferrantelli V (2020) Heavy Metals and PAHs in Meat, Milk, and Seafood From Augusta Area (Southern Italy): Contamination Levels, Dietary Intake, and Human Exposure Assessment. Frontiers in Public Health 8:273. https://doi.org/10.3389/fpubh.2020.00273

10. EFSA (European Food Safety Authority) (2010) Scientific Opinion on Lead in Food. The EFSA Journal $8(4): 1570$

11. EFSA (European Food Safety Authority) (2011a) Statement on the Evaluation on a New Study Related to the bioavailability of aluminum in food. The EFSA Journal 9(5):2157

12. EFSA (European Food Safety Authority) (2011b) Panel on Contaminants in the Food Chain (CONTAM). Statement on tolerable weekly intake for cadmium. The EFSA Journal 9(2), 1975

13. EFSA (European Food Safety Authority) (2015) Scientific Opinion on the risks to public health related to the presence of nickel in food and drinking water. The EFSA Journal 13(2):4002-4204 
14. González-Weller D, Rubio C, Gutiérrez AJ, Pérez B, Hernández-Sánchez C, Caballero JM, Revert C, Hardisson A (2015) Dietary content and evaluation of metals in four types of tea (white, black, red and green) consumed by the population of the Canary Islands. Pharmacological Analytica Acta 6(10):428

15. Gu YG, Gao YP, Lin Q (2016) Contamination, bioaccessibility and human health risk of heavy metals in exposed-lawn soils from 28 urban parks in southern China's largest city, Guangzhou. Appl Geochem $67: 52-58$

16. Gutiérrez AJ, González-Weller D, González T, Burgos A, Lozano G, Hardisson A (2008) Content of trace metals (iron, zinc, manganese, chromium, copper, nikel) in canned variegated scallops (Chlamys varia). International Journal of Food Science Nutrition 59:535-543

17. Hardisson A, Revert C, González-Weller D, Gutiérrez A, Paz S, Rubio C (2017) Aluminium Exposure Through the Diet. HSOA Journal of Food Science Nutrition 3:019

18. Hardisson A, Rubio C, Báez A, Martín MM, Álvarez R, Díaz E (2001) Mineral composition of the banana (Musa acuminata) from the island of Tenerife. Food Chem 73:153-161

19. Heller MC, Willits-Smith A, Meyer R, Keoleian GA, Rose D (2018) Greenhouse gas emissions and energy use associated with production of individual self-selected US diets. Environmental Research Letters 13(4):044004. https://doi.org/10.1088/1748-9326/aab0ac

20. Hendrie GA, Baird D, Ridoutt B, Hadjikakou M, Noakes M (2016) Overconsumption of Energy and Excessive Discretionary Food Intake Inflates Dietary Greenhouse Gas Emissions in Australia. Nutrients 8(11):690. https://doi.org/10.3390/nu8110690

21. Hornick SB (2009) Factors affecting the nutritional quality of crops. Am J Altern Agric 7:63-68

22. IOM (Institute of Medicine) (2001) Dietary Reference Intakes for. In: Vitamin A, Vitamin K, Arsenic Boron, Chromium, Copper, lodine, Iron, Manganese, Molybdenum, Nickel, Silicon, Vanadium, and Zinc. Food and Nutrition Board, Institute of Medicine, National Academies, Washington

23. IUPAC (1995) International Union of Pure and Applied Chemistry, nomenclature in evaluation of analytical methods including detection and quantification capabilities. Pure Appl Chem 67:1699-1723

24. Jaudenes JR, Hardisson A, Paz S, Rubio C, Gutiérrez AJ, Burgos A, Revert C (2017) Potentiometric Determination of Fluoride Concentration in Beers. Biological Trace Element Research. https://doi.org/10.1007/s12011-017-1029-8

25. Karasakal A (2020) Determination of Trace and Major Elements in Vegan Milk and Oils by ICP-OES After Microwave Digestion. Biol Trace Elem Res 197:683-693. https://doi.org/10.1007/s12011-019-02024-7

26. Karppanen H, Mervaala E (2006) Sodium Intake and Hypertension. Prog Cardiovasc Dis 49(2):59-75

27. Kato M, Ohgami N, Ohnuma S, Hashimoto K, Tazaki A, Xu H, Kondo-Ida L, Yuan T, Tsuchiyama T, He T, Kurniasari F, Gu Y, Chen W, Deng Y, Komuro K, Tong K, Yajima I (2020) Multidisciplinary approach to assess the toxicities of arsenic and barium in drinking water. Environ Health Prev Med 25(16). https://doi.org/10.1186/s12199-020-00855-8

28. Khan N, Ryu KY, Choi JY, Nho EY, Habte G, Choi H, Kim MH, Park KS, Kim KS (2015) Determination of toxic metals and speciation of arsenic in seaweeds from South Korea. Food Chem 169:464-470

29. Kosečková P, Zvěřina O, Pruša T, Coufalík P, Hrežová E (2020) Estimation of cadmium load from soybeans and soy-based foods for vegetarians. Environ Monit Assess 192:89. https://doi.org/10.1007/s10661-019- 
8034-7

30. Krajčovičová-Kudláčková M, Ursínyová M, Mašánová V, Béderová A, Valachovičová M (2006) Cadmium Blood Concentrations in Relation to Nutrition. Central Europe Journal of Public Health 14(3):126-129

31. Kumar S, Sharma A (2019) Cadmium toxicity: effects on human reproduction and fertility. Rev Environ Health 34(4):327-338

32. Lee AH, Su D, Pasalich M, Tang L, Binns CW, Qiu L (2014) Soy and isoflavone intake associated with reduced risk of ovarian cancer in southern Chinese women. Nutr Res 34:302-307

33. Liu Z, Li W, Sun J, Liu C, Zeng Q, Huang J, Yu B, Huo J (2004) Intake of soy foods and soy isoflavones by rural adult women in China. Asia Pacific Journal of Clinical Nutrition 13(2):204-209

34. Marini M, Angouria-Tsorochidou E, Caro D, Thomsen M (2021) Daily intake of heavy metals and minerals in food - A case study of four Danish dietary profiles. J Clean Prod 280:124279. https://doi.org/10.1016/j.jclepro.2020.124279

35. Meng S, Chang S, Gillen AM, Zhang Y (2016) Protein and quality analyses of accessions from the USDA soybean germplasm collection for tofu production. Food Chem 213:31-39

36. Mejia A, Harwatt H, Jaceldo-Siegl K, Sranacharoenpong K, Soret S, Sabaté J (2017) Greenhouse Gas Emissions Generated by Tofu Production: A Case Study. Journal of Hunger Environmental Nutrition 13(1):131-142. https://doi.org/10.1080/19320248.2017.1315323

37. Mourouti N, Panagiotakos DB (2013) Soy food consumption breast cancer Maturitas 76:118-122

38. Nordberg GF, Fowler BA, Nordberg M, Friberg L (2007) Handbook on the Toxicology of Metals, 3rd edn. Academic Press, Amsterdam

39. Ogimoto M, Suzuki K, Haneishi N, Kikuchi Y, Takanashi M, Tomioka N, Uematsu Y, Monma K (2016) Aluminium content of foods originating from aluminium-containing food additives. Food Additives Contaminants: Part B 9(3):185-190. https://doi.org/10.1080/19393210.2016.1158210

40. Oliveira VM, Rodrigo Dias Assis C, Silva Costa HM, Pereira Freitas Silva R, Ferreira Santos J, Carvalho B, Bezerra LJr,S, R (2017) Aluminium sulfate exposure: A set of effects on hydrolases from brain, muscle and digestive tract of juvenile Nile tilapia (Oreochromis niloticus). Comp Biochem Physiol C: Toxicol Pharmacol 191:101-108. https://doi.org/10.1016/j.cbpc.2016.10.002

41. Pastircakova K (2004) Determination of trace metal concentrations in ashes from various biomass materials. Energy Education Science Technology Part A: Energy Science Research 13(2):97-104

42. Pathak P, Gupta DK (2020) Strontium Contamination in the Environment. The Handbook of Environmental Chemistry. Springer, Switzerland. https://doi.org/10.1007/978-3-030-15314-4

43. Paz S, Rubio C, Gutiérrez AJ, González-Weller D, Hardisson A (2020) Dietary Intake of Essential Elements (Na, K, Mg, Ca, Mn, Zn, Fe, Cu, Mo, Co) from Tofu Consumption. Biological Trace Element Research. https://doi.org/10.1007/s12011-020-02151-6

44. Queirolo F, Valenta P, Stegen S, Breckle SW (1990) Heavy metal concentrations in oak wood growth rings from the Taunus (Federal Repubic of Germany) and the Valdivia (Chile) regions. Trees 4(2):81-87

45. Rodríguez M, Gutiérrez AJ, Rodríguez N, Rubio C, Paz S, Martín V, Revert C, Hardisson A (2018) Assessment of mercury content in Panga (Pangasius hypophthalmus). Chemosphere 196:53-57 
46. Rubio C, González-Iglesias T, Revert C, Reguera Jl, Gutiérrez AJ, Hardisson A (2005) Lead Dietary Intake in a Spanish Population (Canary Islands). J Agric Food Chem 53:6543-6549

47. Rubio C, Napoleone G, Luis-González G, Gutiérrez AJ, González-Weller D, Hardisson A, Revert C (2017b) Metals in edible seaweed. Chemosphere 173:572-579

48. Rubio C, Paz S, Ojeda I, Gutiérrez AJ, González-Weller D, Hardisson A, Revert C (2017a) Dietary Intake of Metals from Fresh Cage-Reared Hens' Eggs in Tenerife, Canary Islands. J Food Qual. https://doi.org/10.1155/2017/5972153

49. SCHER (Scientific Committee on Health and Environmental Risk) (2012) Assessment of the Tolerable Daily Intake of Barium. European Commission. https://doi.org/10.2772/49651

50. Serrazanetti DI, Ndagijimana M, Miserochi C, Perillo L, Guerzoni ME (2013) Fermented tofu: Enhancement of keeping quality and sensorial properties. Food Control 34:336-346

51. Shaheen N, Irfan NM, Khan IN, Islam S, Ahmed MK (2016) Presence of heavy metal in fruits and vegetables: Health risk implications in Bangladesh. Chemosphere 152:431-438

52. Tóth G, Hermann T, Da Silva MR, Montanarella L (2016) Heavy metals in agricultural soils of the European Union with implications for food safety. Environmental International 88:299-309

53. WHO (World Health Organization) (2010) Strontium and strontium compound. Concise International Chemical Assessment Document 77:1-63

54. Xu L, Du B, Xu B (2015) A systematic, comparative study on the beneficial health components and antioxidant activities of commercially fermented soy products marketed in China. Food Chem 174:202213

\section{Figures}


TOFU

CONSUMER GUIDELINES

Risk free

Slight risk

High risk

Extreme risk

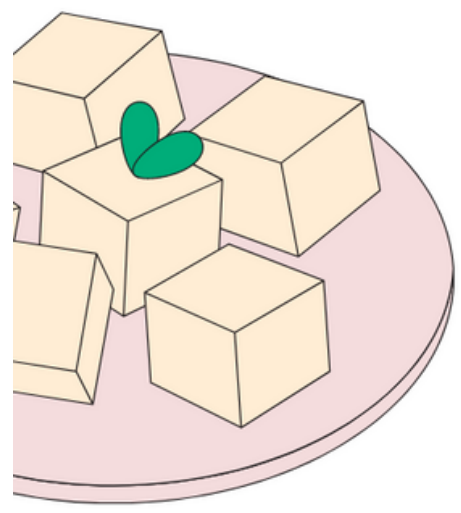

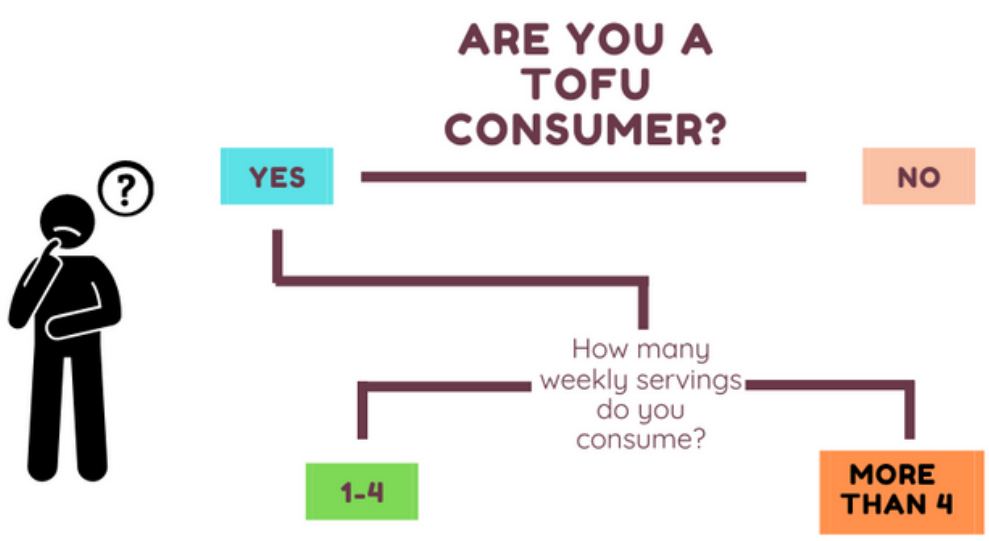

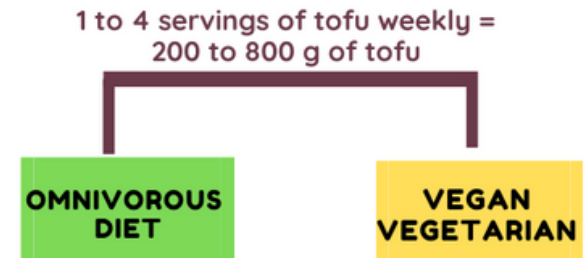

1) Vary between tofu types.

No special recommendations.
2) Reduce the soybean derived products (like soybean

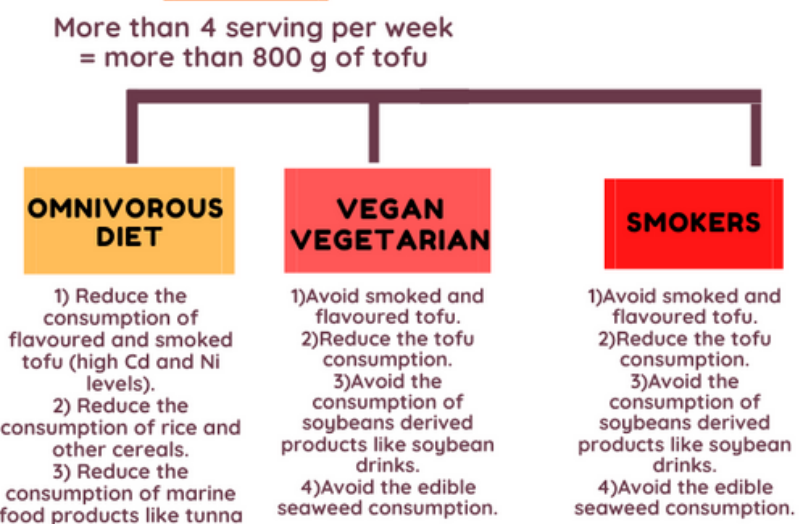

Figure 1

Tofu consumer guidelines for an adult 